\title{
Impacts of Employee Development and Marketing Capacity on Product Innovation: A Case of Small and Medium Enterprises in Vietnam
}

\author{
Le Manh Tung \\ Commission for the Management of State Capital at Enterprises, Hanoi, Vietnam
}

\begin{abstract}
This research aims at examining the impacts of employee development and marketing capacity on product innovation of small and medium enterprises (SMEs) in Hanoi. After 3 month of collecting data, the author received 287 responses and 249 responses left after refining. The findings from the research indicate that there are positive impacts of employee development and marketing capacity on product innovation of SEMs. However, marketing capacity had the stronger impact on product innovation. The findings confirm that the theories on impacts of employee development and marketing capacity on product innovation can be applied in the context of SMEs in Vietnam. In order to improve product innovation, SMEs need to pay attention to both employee development and improving marketing capacity.
\end{abstract}

Keywords: employee development, marketing capacity, employee development

DOI: $10.7176 / \mathrm{EJBM} / 12-15-09$

Publication date:May $31^{\text {st }} 2020$

\section{Introduction}

Studies on small and medium enterprises (SMEs), even from different points of view, all agree that SMEs were an important driving force of economic growth (Pham, 2007). The development of the SMEs helped create more jobs, raise incomes, and improve quality of life. In Vietnam, during the period 2010-2017, SMEs accounted for 98.1\% of the total number of operating enterprises, contributing about $45 \%$ of GDP, $31 \%$ of total state budget revenue. On average, in the period of 2012-2017, the number of SMEs increased by $8.8 \%$, higher than the average growth of large enterprises of 5.4\% (Dong, 2019). However, as Vietnam's market becomes more and more open (according to the committed integration roadmap), SMEs in Vietnam have to deal with increasing international competition. However, as in other developing countries, SMEs in Vietnam are still week in terms of product innovation. According to findings from the National Survey, innovation activities in Vietnamese enterprises in general and processing and manufacturing enterprises in particular are not strong, the rate of enterprises having innovation activities is still low and the level of Innovation is still limited (Anh, 2019).

Meanwhile, Porter (1985) asserts that product innovation is one of the principle factors affecting the competitiveness of an enterprise. According to Gronhaug and Kaufmann (1988), product innovation has become increasingly important to the competitive advantage of enterprises. Product innovation allows enterprises to be ahead of their competitors, create market barriers, and establish a leading position in the market (Mu et al, 2009). Similarly, Akgu, Keskina, Byrne, and Aren (2007) found that product innovation has a positive relationship with profitability and market share. More recently, Nguyen (2016) found product innovation has a positive effect on business performances in Vietnam. Therefore, in the context of SMEs in Vietnam, it is important to improve product innovation rate. However, to do so, it is necessary to examine factors affecting product innovation.

Meanwhile, various studies indicate that employee development and marketing capacity have strong potential to affect product innovation. Regarding employee development, Blundell et al. (1999) argue that training is essential to impart knowledge for developing workers skills. Particularly, training enhances assimilation of knowledge that promotes learning (Tsinopoulos et al., 2018); therefore, has positive impacts on innovation (Dostie, 2017; Forés and Camisón, 2016). Medase and Barasa (2019) argue that marketing capabilities can help enterprises to identify and react to competitors' actions, technological advance and modernization. Marketing capabilities also allow enterprises to predict customer specific and concealed demands. These capabilities have positive impacts on ability of the enterprise to launch either new products or improved products.

However, currently impacts of employee development and marketing capacity on product innovation in Vietnam have not received adequate attention in literature. Therefore, it is imperative to study the impacts of employee development and marketing capacity on product innovation of small and medium enterprises in Vietnam in current contexts.

\section{Literature Review}

\subsection{Product innovation}

Chen and Liu (2005) consider product innovation as the planning and realization processes that create or rebuild a new technological system and provide the necessary functions to satisfy the needs of customers. The ultimate 
goal of product innovation is to provide a solution that can be used or accepted by the customers. According to Damanpour and Gopaiakrishnan (2001), product innovation is defined as the creation of new products or services to meet the external user or market demand. Similarly, According to Wang and Ahmed (2004), product innovation reflects the novelty and meaningfulness of new products introduced to the market in a timely fashion.

Porter (1985) asserts that product innovation is one of the principle factors affecting the competitiveness of an enterprise. According to Gronhaug and Kaufmann (1988), product innovation has become increasingly important to the competitive advantage of enterprises. Product innovation allows enterprises to be ahead of their competitors, create market barriers, and establish a leading position in the market (Mu et al, 2009). Similarly, Akgu, Keskina, Byrne, and Aren (2007) found that product innovation capacity has a positive relationship with profitability and market share.

\subsection{Employee development and product innovation}

According to Orr, Bush, and Vorhies (2011), employee development is defined as the activities performed systematically and routinely to maintain and enhance the knowledge and skills of employees. According to Newbert (2007), employee development is implemented through human resource practices, especially through training and compensation. Cenzo and Robbins (1994) defined employment development as a process that allows employees to acquire new knowledge, learn new skills, change attitudes and behaviors, and to improve personal performance. According to Wayne (1992), the concepts of training and development can be used interchangeably and consist of programs that are planned to improve performance at all levels: individual, group, and enterprise. These improvements lead to systematic changes in the evaluation of knowledge, skills, attitudes, and social behavior. Bishop (2003) and Haksever (2005) explained training helps workers master specific new skills and capacities that improve their performance or better take on new responsibilities.

Existing literature suggest positive impacts of employee development on product innovation. Blundell et al. (1999) argue that training is essential to impart knowledge for developing workers skills. Particularly, training enhances assimilation of knowledge that promotes learning (Tsinopoulos et al., 2018); therefore, has positive impacts on innovation (Dostie, 2017; Forés and Camisón, 2016). In addition, there are training programs focusing on development or introduction of new products, therefore, directly affecting product innovation (Michaelis and Markham, 2017). Similarly, Malik, Pereira \& Tarba (2017) found that a number of scientific employees were engaged in exploratory learning conducive to the generation of new patents and product innovation. OyelaranOyeyinka and Lal (2006) demonstrate that training is an essential source of knowledge accumulation that is positively associated with innovation. More recently, Medase and Barasa (2019) argued and found that formal training facilitates the assimilation and use of external knowledge that enhances innovation.

The above arguments and evidences indicate that:

Hypothesis 1: There is a positive impact of employee development on product innovation.

\subsection{Marketing capability and product innovation}

According to Yama, Guan, Pun, and Tang (2004), marketing capability is an enterprise's ability to publicize and sell products on the basis of understanding a consumer needs, the competitive environment, the costs and benefits, and the acceptance of the innovation. Similarly, according to Drucker (1993), marketing capacity is the capacity to recognize the market segments based on needs and customer characteristics, and the capacity to develop unique marketing positions for products or services in the minds of the target customers. In the same way, Song and Benedetto et al (2007) considered marketing capability as the ability of an enterprise to use its tangible and intangible resources to understand complex consumer specific needs, achieve product differentiation relative to competing products, and achieve superior brand equity. Vorhies and Morgan (2005) found that strong marketing capacity allows enterprises to leverage other resources for better competitive advantages. As Narsimhan et al (2006) explain that an enterprise giving more resources for communicating with customers is more sensitive to the market. Market sensitivity becomes an inimitable resource of the enterprise. According to Song et al. (2008), marketing capacity supports an enterprise in creating strong connections with customers and distributors. In addition, marketing capacity contributes to a stronger brand. Burkitt and Zealley (2006) assert that marketing capacity helps increase customer satisfaction, boosts market share, and raises profitability and productivity of employees. Therefore, marketing capabilities play a crucial role in keeping market-orientation of enterprises. Davis (2007) asserts that every enterprise is facing a situation in which their customers are being drawn to wise competitors; as such, the key task of the marketing activities is to attract and retain customers.

Regarding product innovation, marketing capabilities reflect an enterprise's abilities to differentiate its products from those of competitors and to connect with consumers to create profitable relationships for innovation (Egbetokun, 2015). Previous studies also found marketing capabilities influenced impactiveness of commercialization of innovations (Ren et al., 2015). Similarly, Mu (2015) found that marketing capability is positively associated with new product development. Recently, Medase and Barasa (2019) argue that marketing capabilities can help enterprises to identify and react to competitors' actions, technological advance and 
modernization. Marketing capabilities also allow enterprises to predict customer specific and concealed demands. These capabilities have positive impacts on ability of the enterprise to launch either new products or improved products.

The above arguments and evidences indicate that:

Hypothesis 2: There is a positive impact of marketing capability and product innovation.

\subsection{Summary of research model}

The summary of the above hypotheses is depicted in the research model in Figure 1. According to this model, employee development and marketing capacity have positive impacts on product innovation.

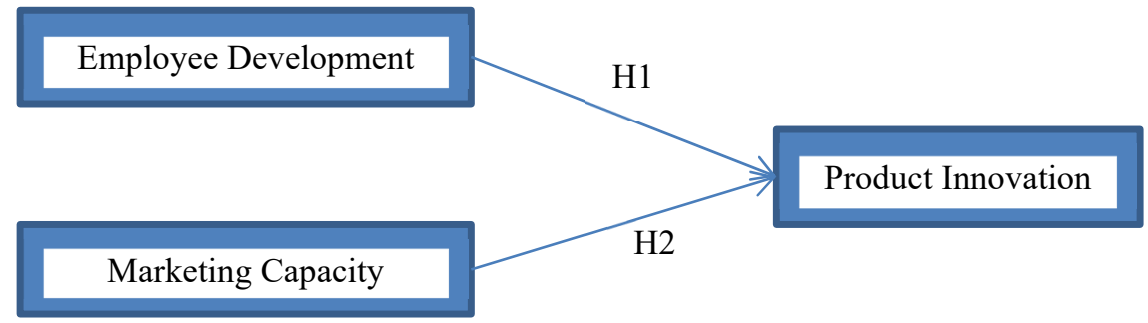

Figure 1: Research Model

\section{Research Methods}

\subsection{Sample}

This study applies the systematic sampling method. The sample was selected based on a business directory in Hanoi. From this list 1000 enterprises were selected purposively. After 3 months of data collection, the author received 287 responses and 249 responses were left after refining. The response rate was about 28.7\%. By business structure, respondents from the Limited Enterprises accounted for 37\%, respondents from Private Enterprises accounted for 28\%, respondents from Joint Stock Enterprises accounted for $27 \%$, and respondents from other business structures accounted for $8 \%$. By gender, $53 \%$ were males, $43 \%$ were females, and $4 \%$ were not specified. By age, respondents aged below 30 accounted for $22 \%$, respondents aged from 31 to 40 accounted for $40 \%$, those aged from 41 to 50 accounted for $31 \%$, and those aged from 51 to 60 accounted for $7 \%$.

\subsection{Measurement Scales}

Employee development was measured via scales developed by Orr, Bush, and Vorhies (2011). Marketing capacity was measured by scales developed by Yama, Guan, Pun, and Tang (2004). Product Innovation was measured via scales developed by Akgu, Keskina, Byrne, and Aren (2007).

\section{Research Findings}

\subsection{Confirmatory factor analysis}

Based on the original scale, we conducted CFA. The results are presented in Figure 2, Table 1, Table 2 and Table 3.

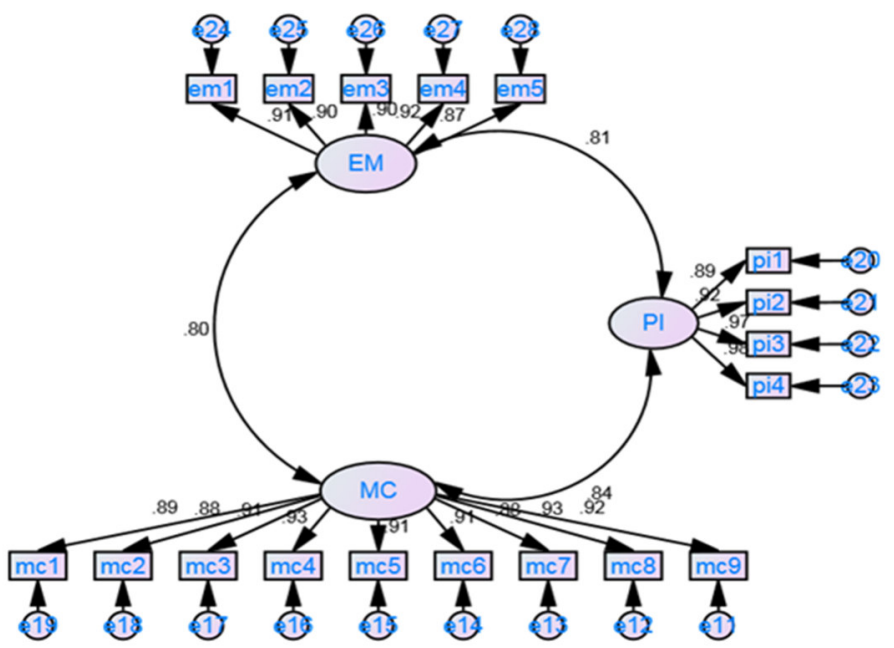

Figure 2: Results from CFA 
The detailed results of CFA for all construct were presented in Table 1. These results showed that the measurement model was well fitted with $1<\mathrm{CMIN} / \mathrm{DF}=2.892<3$ (acceptable); CFI $=0.961$ ( $>0.95)$ (excellent); $0.06<$ RMSEA $<0.08$ (acceptable). All of these model-fit indexes indicate that the whole measurement model was well-fitted.

Table 1: Model fit

\begin{tabular}{|l|l|l|l|}
\hline Measure & Estimate & Threshold & Interpretation \\
\hline CMIN/DF & 2.892 & Between 1 and 3 & Excellent \\
\hline CFI & 0.961 & $>0.95$ & Excellent \\
\hline RMSEA & 0.078 & $<0.08$ & Acceptable \\
\hline
\end{tabular}

To evaluate the measurement model, convergent and discriminant validity tests were conducted. To meet the convergent validity criterion, values of composite reliability $(\mathrm{CR})$ for each construct should be higher than 0.7 . In addition, values of the average variance extracted (AVE) should be greater than the recommended threshold of 0.5. The results in Table 2 indicated that the measurement models of employee development, marketing capacity, and product innovation meet construct reliability and convergent validity criteria.

Table 2: Tests results of convergent validity and reliability

\begin{tabular}{|l|l|l|l|l|l|l|l|}
\hline & CR & AVE & MSV & MaxR(H) & EM & MC & PI \\
\hline EM & 0.955 & 0.808 & 0.653 & 0.956 & 0.899 & & \\
\hline MC & 0.977 & 0.826 & 0.705 & 0.978 & $0.798^{* * *}$ & 0.909 & \\
\hline PI & 0.968 & 0.883 & 0.705 & 0.978 & $0.808^{* * *}$ & $0.840^{* * *}$ & 0.940 \\
\hline
\end{tabular}

To meet discriminant validity requirement, the square root of each construct's AVE should be higher than the correlation of the construct with other latent variables. The results are also presented in Table 2, confirming the good discriminant validity of the measurement model. Employee development, marketing capacity, and product innovation are three different constructs.

Factor loadings of items on the related variables are presented in the Table 3.

Table 3: Factor loading

\begin{tabular}{|c|c|c|}
\hline & Variables/Item & $\begin{array}{l}\text { Factor } \\
\text { loading }\end{array}$ \\
\hline \multirow{5}{*}{$\begin{array}{l}\text { Employee } \\
\text { Development (ED) }\end{array}$} & Routinely provide employees with opportunities for training. & .907 \\
\hline & $\begin{array}{l}\text { Systematically provide employees with regular feedback about their } \\
\text { performance. }\end{array}$ & $.898 * * *$ \\
\hline & Provide regular opportunities for enhancing employee skills. & $.901 * * *$ \\
\hline & $\begin{array}{l}\text { Regularly reward performance as a means of increasing employee } \\
\text { motivation. }\end{array}$ & $.921 * * *$ \\
\hline & $\begin{array}{l}\text { Regularly empowering employees to make decisions about their assigned } \\
\text { tasks. }\end{array}$ & $.866 * * *$ \\
\hline \multirow{9}{*}{$\begin{array}{l}\text { Marketing capacity } \\
(\mathrm{MC})\end{array}$} & Relationship management with major customers. & $.890 * * *$ \\
\hline & Knowledge of different market segments. & $.884 * * *$ \\
\hline & Impactiveness of the marketing intelligence system. & $.912 * * *$ \\
\hline & Impactiveness of marketing information dissemination. & $.926 * * *$ \\
\hline & Distribution efficiency. & $.914 * * *$ \\
\hline & Sales-force efficiency. & $.912 * * *$ \\
\hline & Performance of after-sales services. & $.885 * * *$ \\
\hline & Tracking customer satisfaction level. & $.932 * * *$ \\
\hline & Maintenance of brand image and corporate image. & .924 \\
\hline \multirow[t]{4}{*}{$\begin{array}{l}\text { Product Innovation } \\
\text { (PI) }\end{array}$} & $\begin{array}{l}\text { In new product and service introduction, our enterprise is often first-to- } \\
\text { market. }\end{array}$ & .892 \\
\hline & $\begin{array}{l}\text { Our new products and services are often perceived as very novel by } \\
\text { customers. }\end{array}$ & $.922 * * *$ \\
\hline & $\begin{array}{l}\text { New products and services in our enterprise often take us up against new } \\
\text { competitors. }\end{array}$ & $.965 * * *$ \\
\hline & $\begin{array}{l}\text { In comparison with competitors, our enterprise has introduced more } \\
\text { innovative products and services during the past } 5 \text { years. }\end{array}$ & $.976 * * *$ \\
\hline
\end{tabular}

Significance of Correlations: $* * * \mathrm{p}<0.001$ 
All five initial items of employee development had factor loadings that varied from 0.866 to 0.921 . All nine initial items of marketing capacity had factor loadings that varied from 0.884 to 0.934 . All items of product innovation had factor loadings that varied from 0.892 to 0.976 . The above findings indicate that the measurement scales used in this study were reliable and valid.

\subsection{Descriptive Statistics}

Table 4 presents the descriptive statistics of the studies variables.

Table 4: Descriptive Statistics of the Studied Variables

\begin{tabular}{|c|c|c|c|c|c|}
\hline & $\mathrm{N}$ & Min & Max & Mean & Std. \\
\hline EM & 249 & 1.00 & 5.00 & 3.3 & .94 \\
\hline $\mathrm{MC}$ & 249 & 1.00 & 5.00 & 3.1 & .99 \\
\hline PI & 249 & 1.00 & 5.00 & 3.4 & .92 \\
\hline
\end{tabular}

Scores on employee development (table 4) varied from 1 to 5.0, with an average score of 3.3/5. The standard deviation of employee development is 0.94 . These figures indicate that SMEs had paid relatively good attention to employee development. However, these scores were not sufficient enough; therefore, SMEs should focus more on employee development.

Scores on marketing capacity (table 2) varied from 1 to 5 , with an average score of 3.1/5. The standard deviation of marketing capability scores is 0.99 . These figures indicate that the marketing capacity of SMEs was good. However, the SMEs still have opportunities to improve their marketing capacity.

Scores on product innovation (table 2) varied from 1 to 5 , with an average score of 3,4/5. The standard deviation of product innovation score is 0.92 . These figures indicate that the product innovation at SMEs was good, but they still need to be improved.

\subsection{Hypothesis testing}

We apply the SEM method to simultaneously test the proposed hypotheses (Figure 3, Table 5, and Table 6). The results showed that the structural model was well-fitted $(\mathrm{CMIN} / \mathrm{DF}=2.892 ; \mathrm{CFI}=0.961 ; \mathrm{RMSEA}=0.078)$

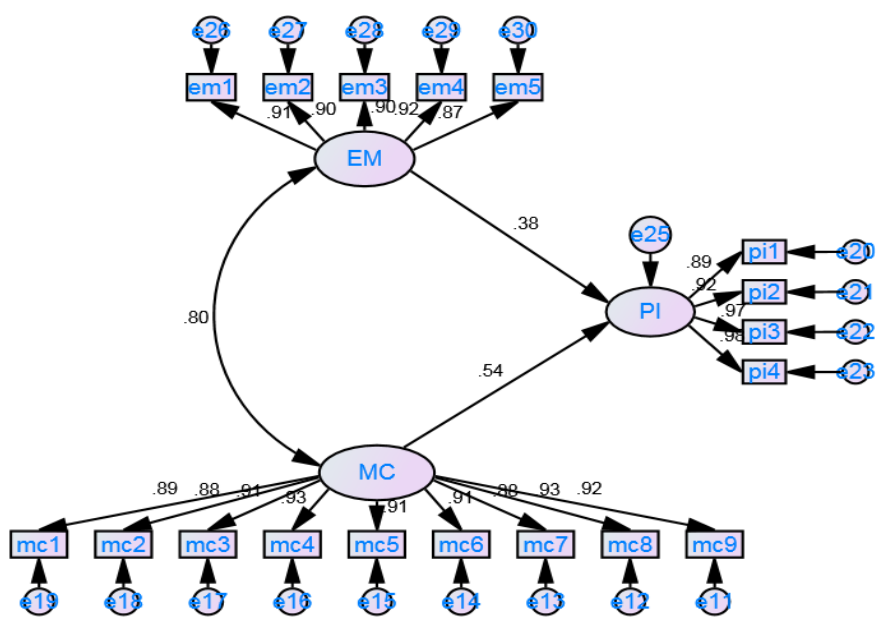

Figure 4: Findings from SEM

Table 5: Model fit

\begin{tabular}{|l|l|l|l|}
\hline Measure & Estimate & Threshold & Interpretation \\
\hline CMIN/DF & 2.892 & Between 1 and 3 & Excellent \\
\hline CFI & 0.961 & $>0.95$ & Excellent \\
\hline RMSEA & 0.078 & $<0.08$ & Acceptable \\
\hline
\end{tabular}

The results of hypotheses testing were presented in the Table 6. The result indicate that employee development (EM) has positive impacts on product innovation (PI) $(\beta=0.380$, at $\alpha \leq 0.001)$, hence $\mathrm{H} 1$ is supported; marketing capacity $(\mathrm{MC})$ also has positive impacts on product innovation (PI) $(\beta=0.537$, at $\alpha \leq 0.001)$, hence $\mathrm{H} 2$ is supported

Table 6: Findings from SEM

\begin{tabular}{|l|l|l|l|}
\hline Predictor & Outcome & Std Beta & Conclusion \\
\hline EM & PI & $.380 * * *$ & H1 is supported \\
\hline MC & PI & $.537 * * *$ & H2 is supported \\
\hline
\end{tabular}

Significance of Correlations: $* * * \mathrm{p}<0.001$ 


\section{Conclusions and recommendations}

\subsection{Conclusions}

The findings indicate that both employee development and Marketing Capacity positive affects product innovation in the context of SMEs in a developing country. Regarding positive impacts of employee development on product innovation, findings in this research were supported by previous research done by Blundell et al. (1999), Tsinopoulos et al.(2018), Dostie (2017), Forés and Camisón (2016), Michaelis and Markham (2017), Malik, Pereira \& Tarba (2017). Regarding the positive impact of marketing capacity on product innovation, findings in this research were supported by Egbetokun (2015), Ren et al., (2015), Mu (2015) and Medase and Barasa (2019).

\subsection{Managerial recommendation}

The above findings suggest several managerial recommendations. The scores on variables employee development (ED), marketing capacity (MC), and product innovation (PI) are, respectively: 3.3/5, 3.1/5, 3.4/5. These scores indicate that SEMs need to find ways to improve product innovation. They can improve product innovation through improving employee development and enhancing marketing capacity. Marketing capacity of SMEs in Vietnam is relatively low, however it has strong effects on product innovation of SMEs; therefore, SMEs in Vietnam should pay a great attention to enhancing marketing capacity. Employee development, in a better status, however, it still needs to improve to strengthening product innovation.

\subsection{Limitations and further research}

This study has the following limitations. Firstly, the sample was drawn from the SMEs in Hanoi; meanwhile the conditions of SMEs in rural areas are maybe different from those of SEMs in Hanoi. Therefore, there are certain limitations in the application of the research results to SMEs in other areas, especially SMEs in rural areas. Secondly, this study was conducted based on the two most interested factors; which are employee development and marketing capability. Therefore, the impact of other internal factors on product innovation of SMEs cannot be answered in this research. To overcome the limitations mentioned above, future studies can be performed according to the following directions:(I) the expansion of the scope of this research to include SMEs in other provinces or conducting a comparative study by comparing the impacts on the above studies factors on product innovation of enterprises operating in different industries, (ii) the inclusion of other internal factors in the research model such as financial capability and organization adaptive capacities.

\section{References}

Akgu, A.E., Keskina, H., Byrne, J.C., Aren, S. (2007). Emotional and learning capability and their impact on product innovativeness and arm performance. Technovation. 27, 501-513

Anh, P. (2019), Đổi mới sáng tạo: Nhìn từ cuộc điều tra thí điểm đầu tiên tại Việt Nam. [Online] Available: http://vneconomy.vn/doi-moi-sang-tao-nhin-tu-cuoc-dieu-tra-thi-diem-dau-tien-tai-viet-nam20190404231537933.htm

Ashish Malik, Vijay Pereira \& Shlomo Tarba (2017). The role of HRM practices in product development: Contextual ambidexterity in a US MNC's subsidiary in India. The International Journal of Human Resource Management. DOI: 10.1080/09585192.2017.1325388

Bishop, K. (2003). Training and entrepreneurship: A partnership whose time has come. Paper presented at the Academy of Management, Seattle, WA.

Blundell, R., Dearden, L., Meghir, C. and Sianesi, B. (1999). Human capital investment: the returns from

Chen, K.M and Liu, R.J (2005).Interface strategies in modular product innovation. Technovation. 771-782

Đong, P.T. (2019), Hỗ trợ doanh nghiệp nhỏ và vừa Việt Nam phát triển trong giai đoạn hiện nay, http://tapchitaichinh.vn/tai-chinh-kinh-doanh/ho-tro-doanh-nghiep-nho-va-vua-viet-nam-phat-trien-tronggiai-doan-hien-nay-314736.html

Dostie, B. (2017). Innovation, productivity, and training. Industrial and Labor Relations Review. 71(1), 64-87.

education and training to the individual, the firm and the economy. Fiscal Studies. 20(1), 1-23.

Egbetokun, A., Oluwadare, A.J., Ajao, B.F. and Jegede, O.O. (2017). Innovation systems research: an agenda for developing countries. Journal of Open Innovation: Technology, Market, and Complexity. 3(25), 1-16.

Forés, B. and Camisón, C. (2016). Does incremental and radical innovation performance depend on different types of knowledge accumulation capabilities and organisational size?.Journal of Business Research. 69(2), 831848.

García-Cruz, J., Real, J. C., \& Roldán, J. L. (2017). Managerial perceptions of employees' affective commitment and product innovation. Economics of Innovation and New Technology. 27(3), 290-305.

Kim, J., Kim, S., \& Park, H. (2015). Factors affecting product innovation performance according to dynamics of environment: evidence from Korean high-tech enterprises in manufacturing sector. International Journal of Technology Management. 67(2/3/4), 269. doi:10.1504/ijtm.2015.068219

Kimura, T., (1993). Present phase of transition to market economy in Vietnam. In Vietnam's dilemmas and options, 
edited by Than, M., and Tan,

Lawrence, S. et al. (2001). Persistence of Web References in Scientific Research. Computer. 34, $26-31$. doi:10.1109/2.901164, http://dx.doi.org/10.1109/2.901164

Medase, K. and Barasa, L. (2019). Absorptive capacity, marketing capabilities, and innovation commercialisation in Nigeria. European Journal of Innovation Management. 22(5), 790-820

Michaelis, T.L. and Markham, S.K. (2017). Innovation training: making innovation a core competency. Research Technology Management. 60(2), 36-42.

Mohamed, H., Ismail, S. A., \& Tarmuchi, N. R. (2018). Factors Influencing Product Innovation Success: The Mediating Impacts of R\&D-Marketing Integration. International Journal of Academic Research in Business and Social Sciences. 8(9), 414-438.

Morgan (1986). International Human Resource Management: Fact or Fiction. Personnel Administrator. 31(9), 437. 47.

$\mathrm{Mu}$, J. (2015). Marketing capability, organizational adaptation and new product development performance. Industrial Marketing Management. 49, 151-166.

Narsimhan, O., Rajiv, S., and Dutta, S. (2006). Absorptive capacity in high technology markets: The competitive advantage of the haves. Marketing Science. 25(5), 510-524.

Nguyen, M.N. (2016). Tác động của nghiên cứu và phát triển, tiếp nhận công nghệ đến kết quả kinh doanh ở các doanh nghiệp chế tạo chế biến (The impact of research and development, technology acquisition on business performance in manufacturing enterprises). Tạp chí kinh tế và phát triển, 225(2), 73-81

Orr, L.M., Bush, V.D. Vorhies, D. W. (2011).Leveraging firm-level marketing capabilities with marketing employee development. Journal of Business Research. 64, 1074-1081

Osoro, O., Vermeulen, P., Knoben, J. and Kahyarara, G. (2016). Impact of knowledge sources on firm-level innovation in Tanzania. Innovation and Development. 6(2), 259-280.

Peter Drucker (1993). The Concept of the Corporation. New Jersey: Transition Publishers.

Pham, M.N (2007). Giải pháp hỗ trợ các doanh nghiệp vừa và nhỏ ở Hà Nội (measures to support small and medium enterprises in Hanoi).

Porter, M. (1985). Competitive Advantage: Creating and Sustaining Superior Performance. New York: The Free Press.

Ren, S., Eisingerich, A.B. and Tsai, H.-T. (2015). How do marketing, research and development capabilities, and degree of internationalization synergistically affect the innovation performance of small and medium-sized enterprises (SMEs)? A panel data study of Chinese SMEs. International Business Review. 24(4), 642-651.

Smith, Joe, (1999), One of Volvo's core values. [Online] Available: http://www.volvo.com/environment/index.htm (July 7, 1999)

Song, M., Benedetto, A. D., and Nason, R. W. (2007). Capabilities and financial performance: The moderating impact of strategic type. Journal of the Academy of Marketing Science. 35, 18-34.

Song, M., Nason, R. W., and Benedetto, A. D. (2008). Distinctive marketing and information technology capabilities and strategic types: A cross national investigation. Journal of International Marketing. 16(1), 4-38

Strunk, W., Jr., \& White, E. B. (1979). The elements of style. (3rd ed.). New York: Macmillan, (Chapter 4).

Tsinopoulos, C., Sousa, C.M.P. and Yan, J. (2018). Process innovation: open innovation and the moderating role of the motivation to achieve legitimacy. Journal of Product Innovation Management. 35(1), 27-48.

Ueasangkomsate, P., \& Jangkot, A. (2017). Enhancing the innovation of small and medium enterprises in food manufacturing through Triple Helix Agents. Kasetsart Journal of Social Sciences. doi:10.1016/j.kjss.2017.12.007

Van der Geer, J., Hanraads, J. A. J., \& Lupton R. A. (2000). The art of writing a scientific article. Journal of Scientific Communications, 163, 51-59

Vorhies, D. W., and Morgan, N. A. (2005). Benchmarking marketing capabilities for sustainable competitive advantage. Journal of Marketing. 69, 80-94

Yama,R.C.M, Guan, J.C, Pun, K.F., Tang, E. P.Y. (2004).An audit of technological innovation capabilities in Chinese firms: some empirical findings in Beijing, China. Research Policy, 33, 1123-1140 